\title{
ACTIVITY MODEL OF PLAYING 'MY HERO IS MY MOTHER' TO IMPROVE BASIC MOVEMENT SKILLS OF MILD MENTAL RETARDED CHILDREN
}

${ }^{1}$ Selvi Atesya Kesumawati, ${ }^{2}$ Tandiyo Rahayu

Correspondence: University of Bina Darma, Palembang, Indonesia

E-mail: selviubd13@gmail.com, tandiyorahayu@mail.unnes.ac.id

\begin{abstract}
Abstrak
Keterampilan gerak dasar anak tunagrahita mengalami gangguan dan memerlukan bantuan dari orang lain untuk dapat mengembangkan potensi geraknya secara maksimal. Tujuan penelitian dan pengembangan gerak dasar melalui aktivitas bermain pada anak tunagrahita diharapkan dapat membantu meningkatkan keterampilan gerak dasar, kemampuan kognitif, kesenangan dan fokus perhatian, sehingga anak tunagrahita memiliki pengalaman yang berharga dalam hidupnya untuk dapat mandiri menjalani kehidupan sehari-harinya. Metode penelitian yang digunakan adalah penelitian dan pengembangan Borg dan Gall. Subjek uji coba kelompok kecil 9 orang siswa tunagrahita dan 4 orang guru, uji coba kelompok besar 21 orang siswa tunagrahita dan 4 orang guru kelas 2 SDLB C kota Palembang. Instrumen penelitian menggunakan skala penilaian. Teknik analisis data menggunakan Content Validity Ratio (CVR) untuk membuktikan tingkat validitas model aktivitas bermain dalam meningkatkan keterampilan gerak dasar siswa, dan menggunakan uji perbedaan untuk membuktikan efektifitas peningkatan hasil gerak dasar siswa kelas 2 SDLB C kota Palembang. Hasil uji validitas model tinggi (CVR 0,475), sehingga model aktivitas bermain ibuku pahlawanku sesuai dengan karakteristik siswa dan efektif untuk meningkatkan gerak dasar, kognitif, kesenangan dan fokus perhatian.
\end{abstract}

\section{Kata Kunci: Model Bermain, Meningkatkan Gerak Dasar Recre a tion}

\section{Abstract}

Fundamental Movement Skills (FMS) of children with intellectual disabilities (ID) had a disruption experience and ID need help from others to develop their potential for movement maximally. The purpose of research and development of FMS through play activities in children with ID was expected to help improve FMS, cognitive abilities, pleasure and focus of attention of children with ID, so that children with ID had valuable experience in their lives, to be able to independently live their daily lives. The research method used was by research and development proposed by Borg and Gall. The subjects of small group trial used 9 children with ID and 4 teachers, and the stages of large group trial used 21 children with ID and 4 teachers in Primary School. The research instrument used rating scale. The data analysis technique was by using Content Validity Ratio (CVR) analysis to prove the validity level of the model of developing FMS through play activities, and used the difference test to prove the effectiveness of 
increasing the FMS results of children with ID in primary school. The results of the validity test model were high (CVR 0.475), so the mother was a hero game model fit the characteristics of children with ID and effective to increase FMS, cognitive, pleasure and focus of attention.

\section{Keywords: Playing Model, Improve Basic Motion}

\section{Introduction}

Every human in this world always wants the best in his life, no one wants to be born in an imperfect condition, or grow and develop according to his age, but there are some pairs of parents who get special deposit from God, for this reason as parents must be prepared physically and mentally in the face of such things, because children are both a gift and a mandate given by God to parents. Children with Special Needs (ABK) are children with special characteristics that are different from children in general. Sabaruddin Yunis (2016) each person has advantages and disadvantages. From these differences it is hoped that we can respect and respect each other's differences.

Mental retardation is an individual who significantly has intelligence below normal intelligence with an intelligence quotient (IQ) score equal to or lower than 70, mental retardation is a disorder that includes slow or below average intellectual function that is IQ 70 below the standard test. Typically mental retardation is differentiated into 4 (four) including: (1) mild mental retardation (IQ 55-69), (2) moderate mental retardation (IQ 40-54), (3) severe mental retardation (IQ 20-39), (4)) mental retardation is very heavy (IQ 20 and below). Twenty-five percent $(25 \%)$ of mental retardation patients whose main causes can be identified are specific identifiable causes which are generally known biological causes, causes of impairment including genetic factors, infectious diseases, accidents, and environmental hazards, Davison et al (2006).

Children with intellectual disabilities are still regarded as children who are a burden on the family and community, because of the limited ability of intelligence below average they cannot live like normal children and this clearly will hamper all activities of their daily lives in socializing, communication and the most prominent is his inability to accept academic subjects as his peers, Kemis and Rosnawati (2013).

The results of observations made by researchers in mentally disabled children in SDLB C Karya Ibu Palembang, found that physical growth did not experience interference even as normal children in general, but had difficulty in learning new things, especially those related to motion, children still looked stiff, less beautiful to looked at, and disproportionate when making movements. The importance of movement, Giriwijoyo (2012) Motion is a characteristic of life, there is no life without motion and what the purpose of life is, if you are unable to move. Maintaining motion is to maintain life, improve the ability to move is to improve the quality of life, therefore "move to live more, don't just move because you are still alive". 
Basic movement skills are basic skills that use limbs and are preliminary patterns for specific and complex skills, as stated by the Department of Education WA (2013) Fundamental Movement Skills (FMS) are movement patterns that involve body parts such as the legs, arms, trunk and head, and include such skills as running, hopping, catching, throwing, striking, and balancing. They are foundation movements or precusor patterns to the more specialized, complex skills use in play, games, sports, dance, gymnastic, outdoor education and physical recreation activities. Somantri (2007) which showed that the physical fitness level of mentally retarded children who have mental abilities at the age of 2 years to 12 years is in the category of very poor, while normal children at the same age are in the poor category.

Based on the description above, the Physical Education learning had a very important role for mentally retarded SDLB C students so that they had effective, efficient and safe basic movement skills so that it was easier to perform the movements needed to live their daily lives, so as to reduce dependency with others. Playing was a fun activity for children. The game itself provided opportunities to practice mentally retarded children's skills repeatedly and developed ideas according to their own abilities therefore physical education had to provide opportunities to play with mentally retarded children in the school environment.

The theme of this game was "My Mother is My Hero". This model consisted of 3 game posts. Each post had a mobile assignment and used different media and tools. Post 1 students made a straight walk (walk forward) on the beam using the tip of the foot (tiptoe), after at the finish line the child mentioned the activity of a mother contained in 4 (four) flashcards. Post 2 students tiptoed around in 4 (four) circles and landed with both feet on the evamatt carpet that had been provided, after in the finish line pinning the clothes according to the instructions provided. Post 3 , students threw from the bottom (underhand throw) towards the target using a ball made of fabric. The objectives to be achieved in this game are (1) increasing the tiptoe on top of the beam, (2) increasing tiptoe skills, (3) increasing the throwing skill from the bottom and (4) increasing cognitive abilities, pleasure and attention focus. Game "My Mother is My Hero" Pos I

$\checkmark$ The child stands ready behind the starting line. After hearing the cue from the teacher (the sound of a whistle) the child immediately makes a walking gesture using toes (tiptoe) on the footpath.

$\checkmark$ Try to keep the child's view straight ahead until the finish line.

$\checkmark$ After being at the finish line, the child picks up and picks up a flashcard containing a picture of a mother's activities and mentions them one by one.

$\checkmark$ After finishing the child leaves the game area and heads to the next post

PJKR

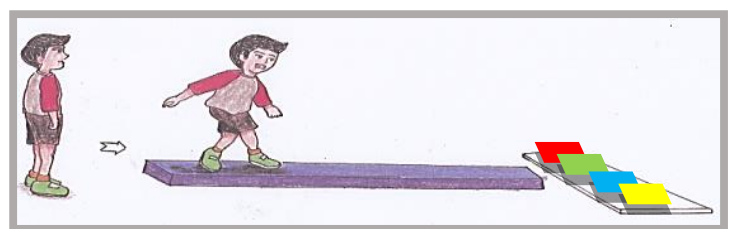

http://jurnal.unimed.ac.id/2012/index.php/jpehr 
Figure 1. My Mother Game Model My Heroes Post 1

Game "My Mother My Hero" Pos 2

$\checkmark$ The child stands ready behind the starting line.

$\checkmark$ After hearing the cue from the teacher the child makes a jumping move of one foot and two feet following the teacher's instructions.

$\checkmark$ After finishing, the child takes a picture containing colorful clothes and pants. The child is asked to sort the picture according to instructions and pin it to the rope (like doing clothes drying activities).

$\checkmark$ After finishing the child leaves the game area and heads to the next post.

Game "My Mother My Hero" Pos 3

Figure 2. My Mother Game Model My Heroes Post 2

$\checkmark$ Children stand ready in a circle behind the line.

$\checkmark$ After hearing the cue from the teacher (whistle sound) the child immediately takes 1 piece of cloth ball and throws (underhand throw) the ball into the basket. The child throws according to the number of balls provided.

$\checkmark$ The teacher counts the number of balls that go into the basket.

$\checkmark$ After finishing the child leaves the game area.

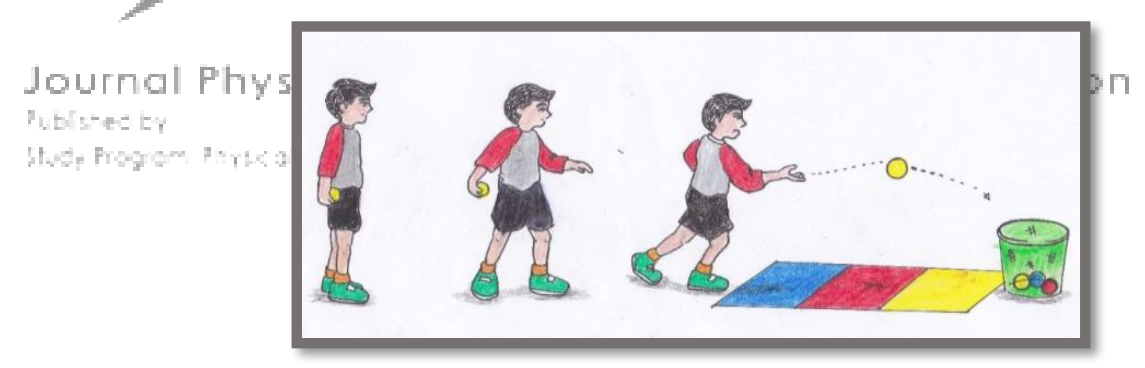

Figure 3. My Mother Game Model My Heroes Post 3

\section{Rating Model Game My Mother My Hero}

Assessment in my mother's game model of my hero uses observation techniques (observations). The task in this game is that students are asked to make tiptoe movements over the beams, tiptoe in 4 circles, and throw the ball from the bottom (underhand throw). The guidelines for scoring basic motion skills, cognitive play, aspects of pleasure, and attention focus can be seen below:

a) Guidelines for Scoring Basic Motion Skills 
Every motion task performed by students will be assessed by a trained teacher / observer, and will score as follows;

Table 1. Guidelines for Scoring Basic Motion Skills

\begin{tabular}{cl}
\hline Score & Item Rating \\
\hline $\mathbf{4}$ & If students can do without the help of others \\
\hline $\mathbf{3}$ & If students can do it with a little help from others \\
\hline $\mathbf{2}$ & If students can do it with the full help of others \\
\hline $\mathbf{1}$ & If students need special guidance to be able to move \\
\hline b) & $\begin{array}{l}\text { Instructions on Game Cognitive Scoring } \\
\text { Each game assignment performed by students will be assessed by a trained } \\
\text { teacher / observer, and will give a score can be seen below: } \\
\text { Table 2. Instructions for Post Cognitive Scoring 1 }\end{array}$ \\
\hline $\mathbf{4}$ & $\begin{array}{l}\text { If students can mention the activities carried out by a mother on a } \\
\text { flashcard appropriately }\end{array}$ \\
\hline $\mathbf{3}$ & $\begin{array}{l}\text { If students try to mention the activities carried out by a mother on a } \\
\text { flashcard even though it is not appropriate / not right }\end{array}$ \\
\hline $\mathbf{1}$ & $\begin{array}{l}\text { If students can mention the activities carried out by a mother on a } \\
\text { flashcard with a little direction from the teacher }\end{array}$ \\
\hline If students can mention the activities carried out by a mother on a \\
flashcard with full help
\end{tabular}

Table 3. Instructions for Post Cognitive Scoring 2

\begin{tabular}{cl} 
Score & Item Rating \\
\hline $\mathbf{4}$ & $\begin{array}{l}\text { if students can pin the picture on the rope that has been provided } \\
\text { according to the instructions picture }\end{array}$ \\
\hline $\mathbf{3}$ & if the student tries to pin the picture on the provided rope even though \\
\hline $\mathbf{2}$ & $\begin{array}{l}\text { it is not according to the instructions in the picture } \\
\text { if students can pin the picture on the rope that has been provided with } \\
\text { direction from the teacher }\end{array}$ \\
\hline $\mathbf{1}$ & $\begin{array}{l}\text { if students can pin the picture on the rope that has been provided with } \\
\text { full help from the teacher }\end{array}$ \\
\hline
\end{tabular}

Table 4. Instructions for Post Cognitive Scoring 3

\begin{tabular}{cl}
\hline Score & \multicolumn{1}{c}{ Item Rating } \\
\hline $\mathbf{4}$ & $\begin{array}{l}\text { If Learners can count the number of balls that enter the basket } \\
\text { correctly }\end{array}$ \\
\hline $\mathbf{3}$ & $\begin{array}{l}\text { If students try to count the number of balls that go into the basket, } \\
\text { even if it is not correct }\end{array}$ \\
\hline $\mathbf{2}$ & $\begin{array}{l}\text { If students can count the number of balls that enter the basket with } \\
\text { direction from the teacher }\end{array}$ \\
\hline $\mathbf{1}$ & If students can count the number of balls that enter the basket with full \\
\hline
\end{tabular}


c) Instructions for Delighting the Aspect of Pleasure

Every fun assignment performed by students will be assessed by a trained teacher / observer, and will give a score can be seen below:

Table 5. Instructions for Fun Aspects

\begin{tabular}{|c|c|}
\hline Score & Item Rating \\
\hline 4 & $\begin{array}{l}\text { If students show cheerful facial expressions and sometimes } \\
\text { accompanied by cheerful laughter }\end{array}$ \\
\hline 3 & $\begin{array}{l}\text { If students show cheerful facial expressions and sometimes smile } \\
\text { broadly while enjoying the game }\end{array}$ \\
\hline 2 & $\begin{array}{l}\text { If students do not show feelings of pleasure (doing whatever they want } \\
\text { and carelessly) }\end{array}$ \\
\hline 1 & $\begin{array}{l}\text { If students do not feel happy (facial expressions are pouting and as if } \\
\text { forced to make movements) }\end{array}$ \\
\hline \multicolumn{2}{|r|}{$\begin{array}{l}\text { Every motion task performed by students will be assessed by a trained teacher } \\
\text { / observer, and will give a score can be seen below: }\end{array}$} \\
\hline \multicolumn{2}{|r|}{ Table 6. Scoring instructions Focus attention } \\
\hline 4 & $\begin{array}{l}\text { If students are yery focused when doing the movement (from } \\
\text { beginning to end, and not disturbed by the circumstances around) }\end{array}$ \\
\hline 3 & $\begin{array}{l}\text { If the focus of the student's attention is disturbed, sometimes still } \\
\text { looking left and right }\end{array}$ \\
\hline 2 & $\begin{array}{l}\text { If students are not focused and often stop when doing a task } \\
\text { assignment }\end{array}$ \\
\hline 1 & $\begin{array}{l}\text { If students are very unfocused and unable to complete the task of } \\
\text { moving }\end{array}$ \\
\hline
\end{tabular}

\section{Method}

The research method used in this research was the research and development of Borg and Gall (1983) by modifying five main steps namely; 1) analyzing the developed product, 2) developing the initial product, 3) Expert validation, 4) empirical validation, 5) product revision. Data collection techniques with a rating scale (rating scale) used in the assessment by 4 experts on the model of 'My mother is my hero' to develop basic movement skills of retarded children in second grade at SDLB C, as well as the assessment of practitioners / teachers in small and large group trials of the activity model of 'My mother is my hero' to develop basic movement skills for retarded children in grade 2 at SDLB C. Small group trial subjects 9 mentally retarded students and 4 teachers, large group trials 21 mentally retarded students and 4 grade 2 SDLB C teachers in Palembang .

Table 7. CVI and CVR Test Results for My Mother's Hero Game

PJKR

http://jurnal.unimed.ac.id/2012/index.php/jpehr 


\begin{tabular}{lllllllllll}
\hline No. & Expert & $\begin{array}{l}\text { Expert } \\
\mathbf{2}\end{array}$ & $\begin{array}{l}\text { Expert } \\
\mathbf{3}\end{array}$ & $\begin{array}{l}\text { Expert } \\
\mathbf{4}\end{array}$ & $\mathbf{n e}$ & $\mathbf{N}$ & $\mathbf{N} / \mathbf{2}$ & $\begin{array}{l}\text { ne- } \\
(\mathbf{N} / \mathbf{2})\end{array}$ & CVR & Criteria \\
\hline 1 & 3 & 4 & 4 & 3 & 2 & 4 & 2 & 0 & 0 & valid \\
\hline 2 & 3 & 4 & 4 & 3 & 2 & 4 & 2 & 0 & 0 & valid \\
\hline 3 & 4 & 4 & 4 & 4 & 4 & 4 & 2 & 2 & 1 & valid \\
\hline 4 & 4 & 4 & 4 & 4 & 4 & 4 & 2 & 2 & 1 & valid \\
\hline 5 & 4 & 4 & 4 & 4 & 4 & 4 & 2 & 2 & 1 & valid \\
\hline 6 & 4 & 3 & 4 & 4 & 3 & 4 & 2 & 1.5 & 0.75 & valid \\
\hline 7 & 4 & 3 & 4 & 4 & 3 & 4 & 2 & 1 & 0.5 & valid \\
\hline 8 & 3 & 3 & 4 & 4 & 2 & 4 & 2 & 0 & 0 & valid \\
\hline 9 & 3 & 3 & 4 & 4 & 2 & 4 & 2 & 0 & 0 & valid \\
\hline 10 & 4 & 3 & 4 & 4 & 3 & 4 & 2 & 1 & 0.5 & valid \\
\hline Total & 36 & 35 & 40 & 38 & Total & & 4.75 & \\
\hline Average & 3.6 & 3.5 & 4 & 3.8 & Average & & 0,475 & Valid \\
\hline Mean & 3.73 & & & &
\end{tabular}

Note: CVR scores for each item range from 1 to -1 .

Small Group Trials

The instrument used to assess the feasibility of the model in this small group trial was in the form of an assessment sheet made by researchers that had been validated by an Expert.

Table 8. Test Implementation by Teachers in Small Groups

\begin{tabular}{ccccc}
\hline No. & Teacher 1 & Teacher $\mathbf{2}$ & Teacher 3 & Teacher $\mathbf{4}$ \\
\hline $\mathbf{1}$ & 3 & 3 & 3 & 4 \\
\hline $\mathbf{2}$ & 3 & 3 & 3 & 4 \\
\hline $\mathbf{3}$ & 4 & 4 & 3 & 3 \\
\hline $\mathbf{4}$ & 4 & 4 & 3 & \\
\hline $\mathbf{5}$ & 3 & 3 & 4 & 4 \\
\hline $\mathbf{6}$ & 4 & 3 & 3 & 4 \\
\hline $\mathbf{7}$ & 4 & 4 & 3 & 4 \\
\hline
\end{tabular}

Tabs 8 above shøwed that the4results of a small group trial of the model of 'My mother

\begin{tabular}{ccccc}
\hline $\mathbf{9}$ & 4 & 4 & 3 & 4 \\
\hline $\mathbf{1 0}$ & 3 & 4 & 3 & 4 \\
\hline Total & 36 & 36 & 31 & 37 \\
\hline Average & 3.6 & 3.6 & 3.1 & 3.7 \\
\hline
\end{tabular}

\section{5}

category; (2) the implementation of the model made it easy for teachers to carry out learning and carried out student assessments, and provide safety, usefulness and enjoyment in learning; (3) the application of play activity models improved learning outcomes of basic motion skills, cognitive abilities, pleasure and focus of attention of students, so that it was followed up by carrying out large group trials.

PJKR

http://jurnal.unimed.ac.id/2012/index.php/jpehr 
The Effectiveness Test of My Mother's Play Activity Model of Heroes by Students

The instrument used to assess the effectiveness of the model of 'My mother is my hero' in my small group trial in the form of a performance test made by researchers to test the effectiveness of the play activity model in improving basic movement skills, cognitive abilities, pleasure and attention focus on students in second grade SDLB C. The results of the effectiveness test and the different models of play activity for aspects of basic motion skills, cognitive abilities, pleasure, and focus of attention on small group trials obtained an average value of trial 2 greater than trial 1 . Likewise, the z-count value of the model activity was greater than the z-table value, so the difference was significant. Then it was concluded that an activity model of 'My mother is my hero' was effective to improve basic movement skills, cognitive abilities, pleasure, and focus of attention of second grade students of SDLB C.

Large Group Trial

The instrument used to assess the feasibility of the model in this large group trial was in the form of an assessment sheet made by researchers that had been validated by an Expert.

Table 9. Implementation Tests by Teachers in Large Groups

\begin{tabular}{ccccc}
\hline No. & Teacher & Teacher 2 & Teacher 3 & Teacher 4 \\
\hline $\mathbf{1}$ & 4 & 3 & 4 & 4 \\
\hline $\mathbf{2}$ & 4 & 4 & 4 & 3 \\
\hline $\mathbf{3}$ & 4 & 4 & 4 & 4 \\
\hline $\mathbf{4}$ & 3 & 4 & 4 & 4 \\
\hline $\mathbf{5}$ & 4 & 3 & 4 & 4 \\
\hline $\mathbf{6}$ & 4 & 3 & 4 & 4 \\
\hline $\mathbf{7}$ & 3 & 3 & 4 & 4 \\
\hline $\mathbf{8}$ & 3 & 4 & 4 & 4 \\
\hline $\mathbf{9}$ & 3 & 4 & 4 & 3 \\
\hline $\mathbf{1 0}$ & 3 & 4 & 4 & 4 \\
\hline Total & 35 & 37 & 40 & 38 \\
\hline Average & 3.5 & 3.7 & 4 & 3.8 \\
\hline & & $\mathbf{3 . 7 5}$ & & \\
\hline
\end{tabular}

Table 9 above showed that the results of a large group trial of my mother's play activity model reached an average of 3.75 with good criteria which means that the application of an activity model of 'My mother is my hero' obtained results: (1) the suitability of the substance content and accuracy of the contents included in the high category; (2) the implementation of the model makes it easy for teachers to carry out learning and carry out student assessments, and provide safety, usefulness and enjoyment in learning; (3) the application of play activity 
models can improve learning outcomes of basic motion skills, cognitive abilities, pleasure and focus of attention of students.

The Effectiveness Test of My Mother's Play Activity Model of Heroes by Students

The instrument used to assess the effectiveness of the model of 'My mother is my hero' in large group trial in the form of a performance test made by researchers to test the effectiveness of the play activity model in improving basic motion skills, cognitive abilities, pleasure and attention focus on students in grade 2 SDLB C. The results of the effectiveness test and the different models of play activity for aspects of basic motion skills, cognitive abilities, pleasure, and focus of attention on large group trials obtained an average value of trial 2 greater than trial 1. Likewise, the $\mathrm{z}$-count value of the model play activity was greater than the z-table value, so the difference was significant. Then it was concluded that my mother's play activity model of my hero was effective to improve basic movement skills, cognitive abilities, pleasure, and focus of attention of second grade students of SDLB C.

\section{Discussion}

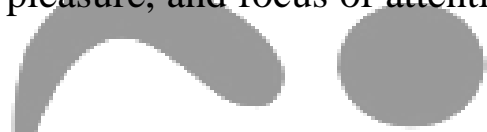

The results of expert validation (CVR analysis) in table 1 on the previous page showed that the draft developed model produced an average CVR value of 0.475 in other words, an activity model of 'My mother is my hero' was appropriate or relevant or good, and also has high content validity, on this basis, then the initial product model of 'My mother is my hero' activity to improve the basic mobility skills of mentally retarded children was said to be good and valid in content.

Development of a model with a play approach was more easily obtained by children through play activities, because there were some benefits derived from play activities that contained physical activities for children were as follows: (1) Wasting extra energy; (2) Optimizing the growth of all parts of the body, such as bones, muscles and organs; (3) Increasing a child's appetite; (4) Learning to control themselves; (5) Developing various skills that will be useful throughout his life; (6) Increasing creativity; (7) Getting the chance to find out the meaning of things around him; (8) Being a way to overcome anger, self-concern, jealousy, and sorrow; (9) Having opportunity to learn to get along with other children; (10) Having opportunity to become a loser or win in playing

Trianto (2007) that the model was said to be good if it fit the criteria one of them is the logical rational theoretical validity. Good learning models, one of which had logical theoretical rational characteristics and learning objectives to be achieved.

An activity model of 'My mother is my hero' which was tested both in small group trials and large group trials was concluded that: (1) The activity model had high content validity in other words this model matched the characteristics of the second grade of retarded children at SDLB C, (2) The implementation of an activity model of 'My mother is my hero' was easily carried 
out by Physical Education teachers at SDLB C, (3) an activity model of 'My mother is my hero' was effective for improving basic movement skills, cognitive abilities, pleasure and attention focus for mentally retarded children 2 SDLB C.

\section{Conclusion}

The conclusion of this study, an activity model of 'My mother is my hero' had high content validity in other words this model was in accordance with the characteristics of the mentally retarded children in second grade in SDLB C. The implementation of an activity model of 'My mother is my hero' was easily carried out by the Physical Education teacher at SDLB C. My hero was effective for improving basic movement skill, cognitive ability, pleasure and attention focus for children with intellectual disabilities in Class 2 at SDLB C

\section{References}

Borg dan Gall, 1983. Educational Research, An Introduction. New York and London. Longman Inc.

Davison, G.C., Neale ,J.M., Kring, A.M., 2006. Psikologi Abnormal. Edisi 9. Diterjemahkan oleh: Noermalasari Fajar. Jakarta: PT. Raja Grafindo.

Departement of Education, 2013. Fundamental Movement Skills Learning Teaching and Assessment, Book 1, Preparing Children For An Active And Healthy Lifestyle. Western Australia: Departemen of Education.

Giriwijoyo, H.Y.S, dkk, 2012. Ilmu Kesehatan Olahraga. Bandung: Remaja Rosdakarya.

Kemis dan Ati, Rosnawati, 2013. Pendidikan Anak Berkebutuhan Khusus Tunagrahita. Jakarta Timur: PT. Luxima Metro Media.

Sabaruddin Yunis Bangun, 2016. Pengembangan Pengetahuan Anak Difabel Melalui Pendidikan Jasmani Olahraga dan Outbound. Journal Physical Education, Health and Recreation. Volume: 1, Edisi: 1: 70-77.

Somantri S, 2007. Psikologi Anak Luar Biasa. Bandung: PT. Refika Aditama.

Trianto, 2007. Model-Model Pembelajaran Inovatif Berorientasi Konstruktivistik.

Jakarta: Prestasi Pustaka. 